Harrison, D and Lugosi, $\mathrm{P}$

Tourism culture(s): The Hospitality Dimension.

Harrison, D and Lugosi, P (2013) Tourism culture(s): The Hospitality Dimension. Tourism Recreation Research, 38 (3). pp. 269279.

doi: $10.1080 / 02508281.2013 .11081753$

This version is available: https://radar.brookes.ac.uk/radar/items/0409b224-3264-4363-bd93-5952134c1197/1/

Available on RADAR: July 2016

Copyright $(C$ and Moral Rights are retained by the author(s) and/ or other copyright owners. A copy can be downloaded for personal non-commercial research or study, without prior permission or charge. This item cannot be reproduced or quoted extensively from without first obtaining permission in writing from the copyright holder(s). The content must not be changed in any way or sold commercially in any format or medium without the formal permission of the copyright holders.

This document is the post print version of the journal article. Some differences between the published version and this version may remain and you are advised to consult the published version if you wish to cite from it. 


\title{
TOURISM CULTURE(S): THE HOSPITALITY DIMENSION
}

Published as: Harrison, D. and Lugosi, P. (2013) Tourism culture(s): The hospitality dimension. Tourism Recreation Research, 38(3), 269-279. Please consult the published version if citing.

\author{
David Harrison \\ School of Tourism and Hospitality Management, University of the South Pacific, Suva, Fiji \\ E-mail: davidharrison53@btinternet.com \\ Peter Lugosi \\ Oxford School of Hospitality Management, Oxford Brookes University, Oxford, United Kingdom \\ E-mail: plugosi@brookes.ac.uk
}

\begin{abstract}
The focus of the paper is on tourism culture as it operates where commercial hospitality is on offer, especially at hotels and resorts in developing countries. It is suggested that three quite distinct perspectives can assist in helping us understand this aspect of tourism culture, which emerges where worker and tourist roles inevitably converge and interact. In themselves, such perspectives are not new, but they rarely seem to have been applied in the context of hotels and resorts. The first perspective, derived from the work of Homi Bhabha, conceives of tourism culture as hybrid in nature, operating in a 'third space' between tourist and 'host,' and directs attention to the uncertain and negotiated aspects of tourism culture. In the second, that of the socio-technical system, tourism culture is seen as an interface between, on the one hand, the formal operational rules and procedures designed to deliver an organisation's mission and, on the other hand, the on-going and lived-in cultures brought into the 'system' by tourists and the hospitality providers. The third perspective, that of the total institution, derived from Goffman, focuses to the social and physical boundaries that separate the hotel or resort from the outside world and on the cultural practices that serve to further differentiate it and its population from the outside. It is suggested that use of these perspectives can further our understanding of the nature of tourism at different destinations and the ways hotels and similar institutions impact on both staff members and holidaymakers. As a consequence, they are theoretically, empirically relevant and politically important.
\end{abstract}

Key words: tourism, hospitality, culture, hybridity, socio-technical systems, total institutions, hotels, resorts. 


\section{Introduction}

In the broad anthropological sense, culture may be defined as everything we learn about taking our place in human society and underpins the framing of our world views, our norms and values, and conditions our negotiated path through everyday social reality. It is almost a truism to note that cultures vary considerably across ethnic and national boundaries and affect the performance of organisations (Hofstede, Hofstede and Minkov, 2010) and prioritising culture as an important factor in tourism is hardly new. It runs like a thread through the entire fabric of travel and tourism and the movement of tourists (and other migrants), and the movement of cultures are intimately related. It is indeed the case that 'cultures travel, too' (Rojek and Urry 1997: 10). Culture is a vital conditioning factor in the relationships of tourists and residents of destination areas (Hottola 2004; Pearce 1995 and 2005: 113-134; Reisinger 2009), in the formation and reformation of patterns of everyday life in tourist destinations (Fisher 2004; Grünewald 2002; Pi Sunyer 1989), or in the way policies are determined for tourism development (Schroeder and Sproule Jones 2012). Culture is also at the heart of the tourism 'product,' whether formally sold as 'heritage' or 'cultural tourism' (Harrison and Hitchcock 2005) or presented as an element in the attraction of 'difference' and 'the other.' As such, when marketed to tourists, 'culture' or 'heritage' may bring groups or categories of people together in a common identity (Soper 2008: 55) or, perhaps simultaneously, be the locus of hotly contested identities and perceptions of place (Harrison 2005a and 2005b).

This paper examines the interaction between hospitality and culture. More specifically, it is argued that hospitality spaces (hotels, resorts, cruise ships and service spaces within them, including restaurants, bars and cafes) are focal points in the production of tourism culture(s). The paper suggests that they are particular organisational contexts that facilitate specific embodied experiences, performances of self, modes of interaction and power relationships among the staff and the tourists. In offering a thematic framework for examining the interaction of tourism cultures and hospitality, the paper draws on three conceptual themes: 'third spaces' (Bhabha 1994), 'socio-technical systems' (Ball, Jones, Kirk and Lockwood 2003) and 'total institutions' (Goffman 1968) and thus furthers an appreciation of the role of hospitality spaces within tourism experiences and a framework for understanding both the processes in hospitality spaces and the outcomes of those processes.

\section{Conceptualising Tourism Culture in Hospitality Spaces}

It is possible to talk about tourism cultures and refer, for example, to the tourism culture of the beach (Urbain 2003; Metusela and Waitt 2012), of the British in Majorca (Andrews 2009), of sports tourists, of mountain tourism, and so on. However, more specifically, 'tourism culture' is used here to denote a way of life that characterises the physical and social interface at which tourists and residents meet one another in settings where commercial hospitality is provided. Following Ryan (2003: 280), tourism cultures have a number of characteristics, involving a temporary spatial-temporal distinction from everyday norms and cultural practices, where leisured, hedonistic consumption is central to the consumer experience. Within service encounters, cultural symbols draw on various stereotypes and caricatures; interactions 
between tourists and frontline staff involve shifting superior/inferior relationships; frontline staff and tourists do not fully conform to the habits or norms of their usual peer groups, and communication between tourists and staff may be through intermediaries and partly-spoken languages. In such circumstances, where interaction is often based on relatively basic concepts that are linked to limited domains of behaviour, the potential for misunderstanding is always present.

This conceptualisation of tourism culture does not assume it is a static or objective entity; rather, it recognises that it exists as social practice, performed and reproduced within specific organisational settings. It takes a myriad of forms, depending on the type of tourism and tourist involved and the nature of the destination. Different (sometimes quite radically different) cultures come to meet in a bounded physical space, or even a series of bounded physical spaces operated by commercial hospitality providers, sharing views (to some extent, at least) as to the nature of the institution and their own roles within it. However, tourism culture is essentially fluid, reflecting the different types of tourist and resident occupying the space, who carry with them their own cultures and expectations but who may yet learn attitudes and behaviour patterns from one another via various processes of inner and outer acculturation. In what follows, the emphasis is on tourism culture as it is learned, performed and encountered in situations where commercial hospitality is on offer and, in particular, at hotels and resorts in developing countries. While recognising that hotels and resorts come in many different forms, we consider how they provide organisational spaces that differentially facilitate the ongoing negotiation and (re)construction of tourism cultures.

Hotels and resorts vary in terms of their size, the configuration of the physical service environment or 'servicescape' (Bitner 1992), experiential propositions, service levels and complexity and, importantly for this paper, in terms of the level of social separation for tourists and staff from the everyday norms and cultures that exist outside these spaces. However, academics have begun to conceptualise these as particular bounded spaces of interaction in which established cultural norms and behaviour may be challenged and replaced with alternatives (Berdychevsky, Poria and Uriely 2013; Pritchard and Morgan 2006; Weaver 2005). Various dimensions of experiences within such hospitality spaces have been considered, and from a number of different perspectives. For example, researchers have paid considerable attention to service cultures and the experiences of service workers (Adler and Adler 2004; Mars and Nicod 1984; Sherman 2007). Studies have also examined various aspects of consumer experiences within such hospitality contexts (Knutson, Beck, Kim and Cha 2006, 2009; Walls, Okumus, Wang and Kwun 2011), and related issues as stereotyping in service encounters (Čivre, Knežević, Baruca and Fabjan 2013). However, in the context of commercial hospitality, the emergence of tourism culture remains under-examined and underconceptualised. In response to this gap in knowledge, this paper suggests a thematic framework for understanding and thus researching tourism cultures.

Several conceptual frameworks could be used to assist in understanding the nature of tourism culture, as schematised in figure 1. First, as signalled by Hollinshead (1998), the interface could be described as a third space, a term derived from Bhabha (1994), which is characterised by a 
shifting, negotiable and contestable hybrid culture which is sourced from aspects of tourist and resident cultures but is yet different from both of them.

Secondly, and in tandem with the first perspective, tourism culture could be considered both a key component and outcome of a socio-technical system (Pasmore, Francis, Haldeman and Shani 1982; Trist 1981), which incorporates both technical and social sub-systems. According to this view, what operators, workers and consumers bring to the business - their attitudes, cultures and orientations - is essential to the way the business operates.

Thirdly, it is possible to envisage hotels and resorts as being total institutions, defined by Goffman as a place 'of residence and work where a large number of like-situated individuals, cut off from the wider society for an appreciable period of time, together lead an enclosed, formally administered round of life' (1968: 11).

Figure 1: Tourism culture(s)

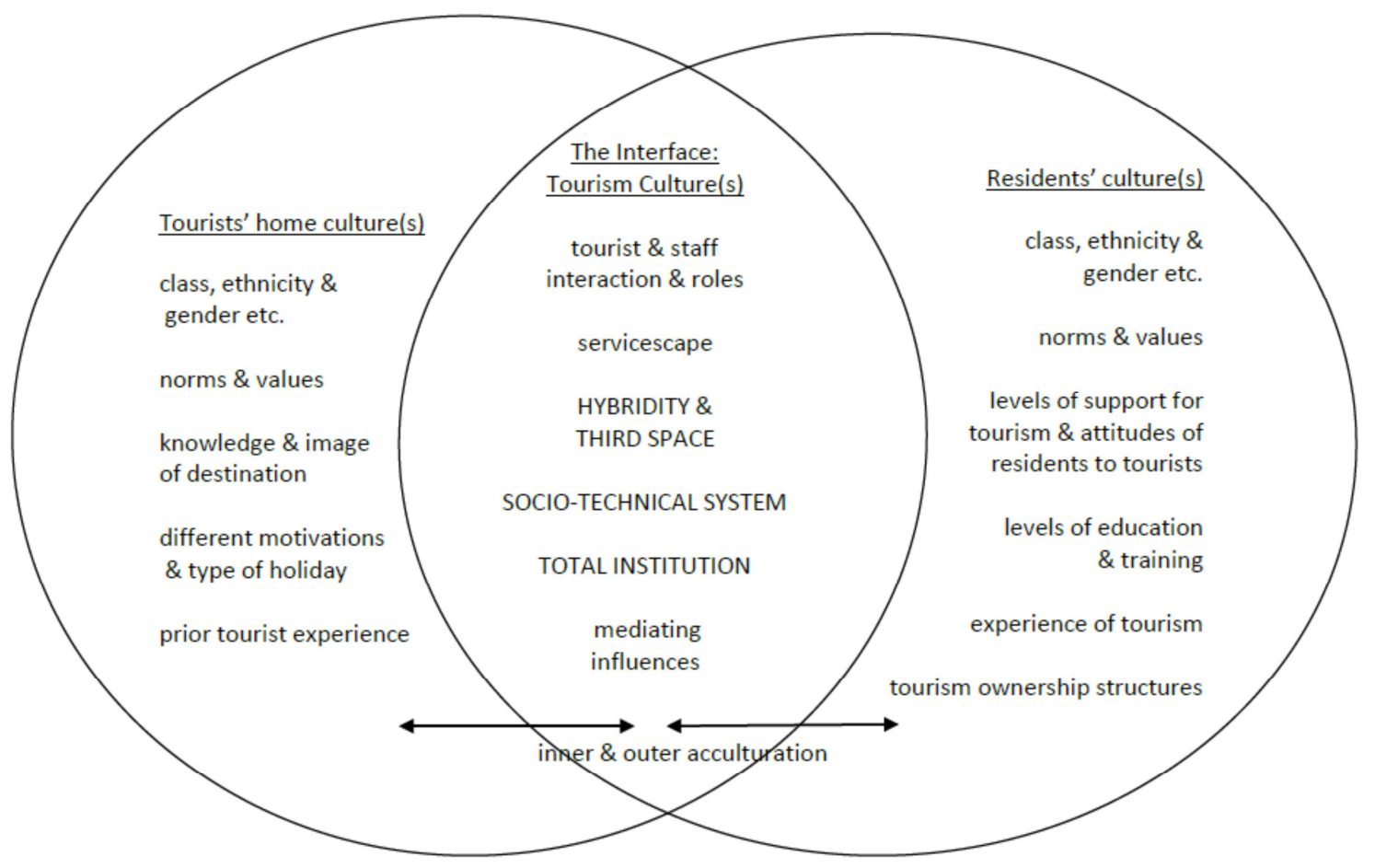

These conceptualisations of hotels and resorts do not exhaust the possible frameworks of analysis. A strong case might also be made, for example, albeit at greater length than this short piece permits, for seeing them as locations of a specific habitus (Bourdieu 1984: 466-484), and it has been argued elsewhere that at least some forms of tourism culture might be considered a distinctive form of quasi-spiritual community or communitas (Graburn 2001: 47-48; Jack and Phipps 2005: 103-105; Turner and Turner 1978: 250). Similarly, while a substantial literature exists on processes of knowledge transfer and creation that characterise work-related migration across international boundaries (Williams 2006), such processes might also operate within national boundaries when workers move to occupational contexts that are markedly 
different from those of their home culture. Elements of such approaches can be found in the three frameworks discussed below which, it is argued, enhance our understanding of the role of hospitality space in developing tourism culture(s).

The framework of analysis adopted for any in-depth study of tourism cultures in hotels and resorts will affect the nature of the data obtained. A third space approach, for instance, directs attention to the uncertainties and negotiated aspects of the tourism culture, to issues of difference and otherness, while analysis from a socio-technical perspective is likely to emphasise the systemic interaction of workers' cultures and its overlaps, differences and contradictions with the technical requirements for operating the business. Finally, analysis of the hotel or resort as a total institution will involve examining the physical and social boundaries that separate the institution from the outside world and the cultural practices within it that serve to further differentiate(and/or protect) it - and its population - from the outside. In the remaining part of this paper, elements of the tourism culture will be discussed to illustrate how these frameworks might be utilised.

\section{Examining Tourism Culture(s) in Hospitality Spaces}

\section{Hospitality Spaces and/as Third Spaces}

Third space reflects a particular conception of culture and identity as fundamentally hybrid; constructions or articulations of both react to, draw on and integrate others or notions of otherness. Bhabha $(1994,1996)$ argued that notions of culture and self should not be seen as a static entities or the fixed property of individuals; instead, they are constantly (re)produced through social engagement and re-interpretation. This perspective suggests that cultures and identities are fluid and subject to change as they are performed in different social and cultural spaces. Identities and cultures are constructed in and through spatial relations (Hall and du Gay 1996; Hetherington 1998), including in hospitality contexts (Lugosi 2009, 2014). The concept of third spaces thus points to particular ways of being, but also reflects the creation of social and cultural spaces in which notions of self are negotiated and articulated.

The extent to which the 'third space,' is distinct from the cultural space(s) occupied by tourists and residents before they enter that of the hotel or resort will depend on the specifics of the situation, but the daily content of any tourism culture is highly fluid. In Hollinshead's terms, 'difference' and 'otherness' (1998: 126-128) converge to be reshaped into a hybrid tourism culture mediated by the physical and social structure of the hotel or resort.

What this means in practical terms can be briefly illustrated by reference to some common scenarios. Focusing primarily on East Africa, Blanton notes several 'barriers to host-guest communication' (1981: 120-125), which, for present purposes, can be seen as issues that emerge in the third space. First, in many developing societies, only a minority of local residents can afford to patronise hotels and resorts, and many will not have visited them. As a 
consequence, for new employees, the physical environment of the hotel may often be quite intimidating. Secondly, attitudes to time vary. Life in many non-industrialised developing societies is less dominated by 'clock time' than in Western societies, a factor that may be marketed as one of the positives of the holiday destination but is less attractive when reflected in slow and (apparently) desultory service or in the non-appearance of staff when they are supposed to be on duty. Finally, whereas social relations in developing societies are based on strong and established kinship ties, those in hotels and resorts are short-term and impersonal (Crick 1989: 331). Tourists and locals encounter each other across a 'mutual gaze' (Maoz 2005), and both must also negotiate relations within their own categories. And where regional or ethnic differences are present, among staff or tourists, social 'reality' can indeed be stressful (Nicholls 2011).

Within hotels and resorts, massive adaptation by staff members might be required. The entire world of food and beverages can be considered a foreign culture and while there is rich material on cross-cultural (and even intra-cultural) social differences in food production, consumption and taste (Douglas 2003), and numerous guides on cultural differences in etiquette (for example, Foster 2000), little attention has been given by tourism researchers to complexities of the gastronomic interface of tourist and residents within hospitality spaces (See e.g. Pratt 2013). In Fiji, for example, owners of backpacker resorts accustomed to subsistence agriculture reportedly do not understand why tourists expect a choice of meals, and the food they offer - or are prohibited from offering - to guests is much influenced by their totemic relationship to specific plants, fish and animals (Gibson 2012). Indeed, even a cursory examination of a standard operational manual for bar staff reveals that basic training is far more than a technical matter: good sanitation and safety procedures and proper food storage seem neutral enough, but cultural factors impinge on the need to know the range of alcoholic drinks sold and their characteristics (including which drinks should be served chilled), understanding how to approach different types of guests and their needs, including those who are drunk, and the projection of a favourable image of self, including making eye contact. And once in the restaurant, not only might the food served to tourists be totally foreign to the staff, but also the array of table cutlery will be daunting, especially if people normally eat with their fingers (Blanton 1981: 124).

Similar cultural issues are present in other areas of hotel and resort life, for example, front office and housekeeping sections. Blanton reports the advice of one hotelier in Indonesia that 'one should start housekeeping training with the concept of a bed, not how to make it' (1981: 124), and suggests that 'industry workers are put into a new cultural environment where their familiar assumptions, values, behavior and ideas are constantly challenged' (Blanton 1981: 125).

The above examples, involving what might has been described as 'culture shock' (Pearce 1995) or 'culture confusion' (Hottola 2004), centre primarily on possible adaptation required by local residents when becoming involved in tourism culture (not the least of which may be to learn a new language). However, adaptation is also required of tourists, especially holidaymakers, and this has been little studied. They may have travelled more than local residents and appear 
more knowledgeable about other parts of the world but, in some respects, their successful participation in tourism culture requires more adaptation. The spectacular faint by Shirley Valentine's friend Jane, in the film Shirley Valentine (1989) set in the Greek Island of Mykonos, on realising she was eating squid, is but one example of a tourist reaction to 'funny food.' Tourists' taste can be highly conservative (Rogerson 2012: 618) and encouragement that they should 'eat local' often falls on deaf ears.

Considerable differences also exist in what is 'acceptable' public behaviour (for example, public displays of affection between couples, especially if they are gay, and in standards of dress or undress, especially for women), which is why so much consideration has been given to 'demonstration effects' (Fisher 2004). Staff from highly conservative societies may find it difficult to tolerate alcohol consumption and the behavioural excesses to which it might lead (Andrews 2009). In this context, it is noteworthy that hotels and resorts are often considered commendable areas of freedom (or Western dens of iniquity) relative to the rest of society.

In fact, learning how not to work, and for only a few intensive days or weeks, might be considered more difficult than learning to be a member of staff at a hotel or resort. Away from home and a work-structured environment, for 24/7 (alone or with family or friends), in what is for most a relatively strange place, tourists must negotiate a modus vivendi to take them through the duration of their stay. They may already be in relationships with their travelling companions, including those which are highly intimate (and which over a holiday period can become highly stressful), but even these will be further mediated through a sense of place (Trauer and Ryan 2005). Just as staff members, from the CEO down to the cleaner, must learn their role in the tourist culture, so too must the tourist. And whereas the former can draw on the organisational structure for support, the latter is more or less on his or her own.

\section{Hospitality Spaces as Socio-technical Systems}

The notion of socio-technical systems refers to the purposive mobilisation of technologies, materials, embodied performances of self, organisational codes, norms and practices in order to maintain efficient operation (Pasmore et al. 1982; Trist 1981) and - within hospitality contexts - to ensure a quality (service or consumption) experience (Ball et al. 2003). To facilitate this, businesses of any size will be organised hierarchically, headed by a CEO, comprised of departments (e.g. food and beverages, front office, housekeeping and human resources) with specific operational rules and procedures, and department heads and supervisors entrusted to ensure conformity to the rules and regulations - to the 'corporate culture' - and to further the hotel or resort's mission. That, any rate, will be the formal structure of the organisation. However, the business does not operate in a socio-cultural vacuum and will be affected by numerous cultural factors introduced by staff and tourists from 'outside,' as well as forms of behaviour that arise specifically from within.

National and regional cultures play their part. As indicated earlier, businesses need punctual and efficient attendance and frequently expect staff to clock on and off, whereas in many 
developing societies this apparent regimentation of life may be quite foreign (Blanton 1981: 122; Hope 2004: 50). McDonald's, for example, must adapt to different cultural expectations in Germany and the UK, which inter alia affects its hiring practices (Royle 1995), as well as the food it serves, while management styles are also subject to considerable cross-cultural variation. Alternatively, expatriate managers at international hotels in Russia must adapt to a hierarchical and paternalistic system descended from the Soviet system, where empowering employees is innovatory and a service ethic is little in evidence (D'Annunzio-Green 2002). Attempts to introduce Western management patterns in Chinese hotels have experienced similar problems (Mwaura, Sutton and Roberts 1998).

Other cultural factors are also important. For example, work-family conflicts are common in the hospitality sector, especially because of the need for shift work and its effects on the non-work roles of women (Choi and Kim 2012; Harrison 1997: 181; Karatepe 2010;). In developing societies, too, staff members may absent themselves from work to attend to kinship or other social obligations, often at short notice, which is often not acceptable to management, especially if expatriate managers have no formal induction into the culture of the developing society (D'Annunzio-Green 2002).

The hotel/resort hierarchy is likely to be based on achievement but in many developing societies status may be based on age. Consequently, if department heads or supervisors are younger than junior staff, conflicts arise, especially if requests from older staff members to younger but more senior colleagues involve contravening the operational procedures of the hotel/resort. Similarly, staff may be discouraged from being over-familiar with and borrowing money from each other or from guests, whereas (in Parsonian terms) local norms might encourage inter-personal behaviour that is particularistic, ascriptive, affective and collective in orientation (Parsons and Shils 1951: 80-88).

Another common rule is for social distance to be maintained between staff members and guests, but guests might seek to reduce the divide by claiming or seeking familiarity with staff members (or vice versa). Where this happens, especially if the guest is drunk, such overtures are likely to be unwelcome; in other circumstances, friendships, romantic attachments and even marriage can result, but in a tourism culture there are also huge risks of misunderstanding and conflict, especially in an alcohol-fuelled environment where inhibitions are reduced and culturally-induced misunderstandings correspondingly exacerbated.

Intoxication, in particular, is not an issue only among guests. It is also an occupational hazard for staff. As O'Neill notes, with specific reference to managers: 'one of the defining characteristics of the hotel industry macroculture may be an emphasis on partying' (2012: 84).

Within tourism culture, the behaviour of some holidaymakers can have a negative impact on the guest experience of others. This can include 'unsupervised children running around, staring, smoking and noticeably drunk [sic], which are all behaviours which vary in their prevalence and acceptability from culture to culture' (Nicholls 2011: 210). Differences may be 
further exacerbated when tourists are from different social classes or national cultures, and thus follow different standards of public behaviour (Nicholls 2011: 214).

At other times, behaviour that is normal in the resident society may intrude on the guest experience. The exuberance of housekeeping staff, accustomed to rising early in the morning, will be unappreciated by hotel guests wanting to 'lie in'. Gibson notes a similar lack of awareness among staff that guests might wish to be quiet (or make love) in the afternoon (2012).

All the above instances may operate against the business's mission, as it is formally expressed, while some features of local or tourists' cultures may be positive. In many developing societies, for example, the 'natural' hospitality and friendliness of local residents is marketed as one of the key attractions. The key point to note, however, is that the variety of cultural orientations brought into the work context by staff and tourists inevitably interact with the formal structure of the organisation to produce a distinctive 'mix' of organisational features which will vary across both time and place.

\section{Hospitality Spaces as Total Institutions}

For Goffman, total institutions are separated, often by physical barriers, from the rest of society, and fall into one of five broad categories: a) those caring for incapable and harmless people (e.g. homes for the blind); b) those looking after people both incapable and a threat to the community (e.g. mental hospitals); c) those that isolate people who apparently deliberately threaten the community (e.g. prisons); d) instrumental institutions (e.g. army barracks, ships and boarding schools), and e) retreats or training stations for the religious (e.g. monasteries) (1968: 16).

Having defined total institutions and suggested possible types, some of which are clearly mechanisms of social control, Goffman then lists several key features likely to be present, to a greater or lesser extent, in any such organisation. Together, they might be said to constitute an 'ideal type' of total institution (Weber 1949: 90-102) and comprise the following (Goffman 1968: 17): individuals sleep, play and work in the same place and under the same single authority. Daily activity 'is carried on in the immediate company of a large batch of others, all of whom are treated alike and required to do the same thing together.' 'All phases of the day's activities are tightly scheduled, with one activity leading at a prearranged time into the next, the whole sequence of activities being imposed from above by a system of explicit formal rulings and a body of officials.' Finally, 'the various enforced activities are brought together into a single rational plan purportedly designed to fulfil the official aims of the institution.'

Goffman did not focus on institutions specialising in providing hospitality but others have recognised the prevalence of social control in many aspects of hospitality and tourism (Cheong and Miller 2000; Lynch, Germann Molz, McIntosh, Lugosi and Lashley 2011; Peacock and Kübler 2001). The highly organised holiday camp, especially popular in the UK in the years following the second World War, perhaps conforms most closely to the ideal type total institution (Read 
1986) but Ritzer and Liska note a 'softer' form of control in cruise ships and hotels (1997: 106). Dann, too, has argued 'whether one is referring to historical or contemporary tourism, the overriding message of order and control is both omnipresent and perennial (1996: 100) and, more relevant to present purposes, he discusses at some length the characteristics of total institutions in holiday hotels organised for the elderly (Dann 2000).

That said, precisely which types of tourism institutions fall into which of the above categories is arguable. However, hotels have been placed on islands far from established population centres to protect the population from 'negative' impacts (e.g. the Maldives) or, alternatively, to protect holidaymakers from everyday life outside the resorts (as in the case of many 'boutique' resorts of the South Pacific and the Caribbean, including all-in resorts). Cruise ships could easily be placed in the fourth category, and while hotels and resorts are not formally religious institutions, the similarities of tourism with pilgrimage and the achievement of communitas are sufficiently established to allow that some hotels or resorts, at least, may have a quasi-religious function (Turner and Turner 1978: 20, 240; Harrison 1997: 178-182).

Table 1

Features of total Institutions and their relevance to hotels and resorts

\begin{tabular}{|l|l|}
\hline $\begin{array}{l}\text { Goffman's characteristics } \\
\text { 1. A split between the } \\
\text { managed group and the } \\
\text { staff. }\end{array}$ & $\begin{array}{l}\text { Found in hotels/resorts. Staff and guest quarters totally separate; } \\
\text { different entrances/exits; staff/guest social relations are clearly } \\
\text { delineated. }\end{array}$ \\
\hline $\begin{array}{l}\text { 2. Restricted } \\
\text { conversation across } \\
\text { boundaries and little } \\
\text { mobility across stratum. }\end{array}$ & $\begin{array}{l}\text { Operational manuals clearly note the need to maintain social } \\
\text { distance from guests and spell out disciplinary measures if rules } \\
\text { are not followed. In addition, restricted access to hotel/resort via } \\
\text { dress codes etc. }\end{array}$ \\
\hline $\begin{array}{l}\text { 3. 'Inmates' are excluded } \\
\text { from decisions about } \\
\text { own lives. }\end{array}$ & $\begin{array}{l}\text { Implicit in hospitality sector. Can operate efficiently only if staff } \\
\text { and guests know their place. Measures designed to ensure health } \\
\text { and safety (e.g. well-lit areas, controlled access of locals, physical } \\
\text { borders, etc.) all serve to control guest behaviour. }\end{array}$ \\
\hline $\begin{array}{l}\text { 4. Mismatch with } \\
\text { society's work structure } \\
\text { (either much more or } \\
\text { much less). }\end{array}$ & $\begin{array}{l}\text { Staff work - sometimes long hours on shift work - but guests do } \\
\text { not. Less relevant in hotels catering primarily to business tourists. }\end{array}$ \\
\hline $\begin{array}{l}\text { 5. Incompatibility with } \\
\text { the family. }\end{array}$ & $\begin{array}{l}\text { In hotels/resorts, family is often subservient to providing service } \\
\text { to guests. }\end{array}$ \\
\hline
\end{tabular}

Other features mentioned by Goffman, which tend to follow from the features common to all total institutions, are also important (1968: 20-22) and can be briefly mentioned in tabular form, along with an indication of their possible relevance to hotels and resorts (Table 1 ). 
Much more could be said about the above features, but further reference here will be made to only a few points. First, in discussing the role of hotels as agents of social control, Wood draws attention to two processes of change: domestication, where hotels increasingly provide 'home comforts' in guests' rooms (to which they are increasingly restricted), and proletarianisation, in that hotels are no longer the preserve of an elite (1994: 74). With reference to the latter process, involving increased guest numbers across a wider range of social classes, he also notes, in passing, that the 'interactional constraints presented by the hotel, as well as more mechanical ones, raise questions about the compatibility of the "industrialisation of service" with the provision of hospitality' (Wood 1994: 78).

Secondly, when discussing the mismatch of the work structure in a total institution (for example, a prison or a hospital) to that of the wider society, Goffman remarks: 'Sometimes so little work is required that inmates, often untrained in leisurely pursuits, suffer extremes of boredom '(1968: 20-21). No great leap of imagination is required to relate this to hotels and resorts, and to consider, in this context, the role of the daily events and activities organised by many hotels and resorts for their guests, including children. The continuous supply of piped or live music, fish-feeding, water sports, horse riding, coconut husking, competitions, dancing, village visits, floor shows and all the other forms of entertainment (or edutainment) found at the world's hotels and resorts serve a double function: they are simultaneously part of the attraction (authentic or otherwise) and a form of social control to allay guest boredom. Arguably, excess alcohol and food consumption may also be more likely when such functions are not being met.

\section{Conclusion}

It has been suggested that distinct 'tourism cultures' are entangled with and emerge from the hospitality interface of resident and guest cultures: they are hybrid cultures which contain elements of both but are yet different, influenced as they are by the operational nature of the hotel or resort. It is also suggested that little research has been carried out on tourism culture in such contexts, and that such conceptual frameworks as the third space, socio-technical systems or total institutions might productively be applied to orientate research and further our understanding of the nature of tourism at different kinds of destinations. They might also assist our understanding of the extent to which different kinds of hospitality organisation have different impacts, on both staff and holidaymaker.

Other issues also emerge. First, although it has been argued that 'industry training is not a "conversion" to another culture, but a specialized form of education which will facilitate service and communication' (Blanton 1981: 120), tourism culture in developing countries is markedly different from the cultures of many (if not most) employees. Exactly how different will vary and can be determined only by research but, even if it is not a 'conversion,' to participate in the tourism culture of hotels, resorts and similar institutions may require radical adaptation by staff members. 
Secondly, such research is not merely a theoretical exercise. Understanding the varieties of tourism culture is of clear value to anyone wishing to plan hospitality and tourism development, whether in the private or the public sector. And if service quality is really important, it has to be based an understanding of the tourism culture at specific destinations. There is no one size that fits all.

Thirdly, the pervasiveness of tourism culture, in all its variety, belies the notion that one can dispense with education for hospitality and tourism and focus, instead, on merely training functionaries to slot into an industrialised hotel sector which allegedly, but probably wrongly, requires 'job-ready applicants' (Zaitouni, Breakey and Robinson 2012). As Blanton noted three decades ago, 'training in social and cultural skills ...should build upon what is already known: it should be a "problem-posing education" which makes [students] critical thinkers' (1981: 125).

In a context where the relevance of universities, in particular, to tourism and hospitality education, is increasingly being questioned (Airey, 2004: 11; Ayikoru, Airey and Tribe, 2009; Tribe, 2000; Holden and Wickens, 2007), and where universities in some developing countries are dispensing with any attempt at producing reflective and critical thinkers, it is a timely reminder that working in hotels and resorts is about more than the ability to fold a table napkin or produce the perfect soufflé. 


\section{References}

ADLER, P. and ADLER, P. (2004). Paradise Laborers: Hotel Work in the Global Economy. Ithaca, NY. Cornell University Press.

AIREY, D. (2004). From Here to Uncertainty. In Tribe, J. and Wickens, E. (Eds) Critical Issues in Tourism Education: Proceedings of the 2004 Conference of the Association for Tourism in Higher Education, Missenden Abbey, Buckinghamshire, UK. $1^{\text {st }}-3^{\text {rd }}$ December.

ANDREWS, H. (2009). 'Tits Out for the Boys and No Back Chat': Gendered Space on Holiday. Space and Culture 12 (2): 166-182.

AYIKORU, M., AIREY, D. and TRIBE, J. (2009). Reading Tourism Education: Neoliberalism Unveiled. Annals of Tourism Research 36 (2): 191-221.

BALL, S., JONES, P., KIRK, D. and LOCKWOOD, A. (2003). Hospitality Operations. A Systems Approach. London: Thomson.

BERDYCHEVSKY, L., PORIA, Y. and URIELY, N. (2013) Hospitality Accommodations and Women's Consensual Sex. International Journal of Hospitality Management 34: 169-171.

BHABHA, H. (1994). The Location of Culture. London and New York. Routledge.

BHABHA, H. (1996). Culture's In-between. In Hall, S. and du Gay, P. (Eds) Questions of Cultural Identity. London. Sage: 53-60.

BITNER, M. J. (1992). Servicescapes: The Impact of Physical Surroundings on Customers and Employees. Journal of Marketing 56 (2): 57-71.

BLANTON, D. (1981). Tourism Training in Developing Countries: The Social and Cultural Dimension. Annals of Tourism Research 8 (1): 116-133.

BOURDIEU, P. (1984). Distinction: A Social Critique of the Judgement of Taste. London. Routledge.

CHEONG, S-M. and MILLER, M. (2000). Power and Tourism: A Foucauldian observation. Annals of Tourism Research 27 (2): 371-390.

CHOI, H. J. and KIM, Y. T. (2012). Work-family Conflict, Work-family Facilitation, and Job Outcomes in the Korean Hotel Industry. International Journal of Contemporary Hospitality Management 24 (7): 1011-1028.

ČIVRE, Z., KNEŽEVIĆ, M., BARUCA, P. and FABJAN, D. (2013). Facial Attractiveness and Stereotypes of Hotel Guests: An Experimental Research. Tourism Management 36 (1): 57-65. 
CRICK, M. (1989). Representations of International Tourism in the Social Sciences: Sun, Sex, Sights, Savings and Servility. Annual Review of Anthropology 18: 307-344.

D'ANNUNZIO-GREEN, N. (2002). An Examination of the Organizational and Cross-cultural Challenges Facing International Hotel Managers in Russia. International Journal of Contemporary Hospitality Management 14 (6): 266-273.

DANN, G. (1996). The Language of Tourism: A Sociolinguistic Perspective. Wallingford. CAB International.

DANN, G. (2000). Overseas Holiday Hotels for the Elderly: Total Bliss of Total Institution? In Robinson, M., Long, P., Evans, N., Sharpley, R. and Swarbrooke, J. (Eds) Reflections on International Tourism: Motivations, Behaviour and Tourist Types. Sunderland. Centre for Travel and Tourism in association with Business Education Publishers: 83-94.

DOUGLAS, M. (2003) Standard Uses of Food: Introduction. In Douglas, M. (Ed) Mary Douglas: Collected Works. Oxon. Routledge: 1-39.

FISHER, D. (2004). The Demonstration Effect Revisited. Annals of Tourism Research 31 (2): 428446.

FOSTER, D. (2000). The Global Etiquette Guide to Asia: Everything you Need to Know for Business and Travel Success. New York. Wiley.

GIBSON, D. (2012). Living in the Moment: Cultural Challenges Faced by Indigenous-owned Budget Resorts in Fiji. Case studies from Wayalai, Yasawa Island Group. Ph.D work in progress: University of the South Pacific.

GOFFMAN, E. (1968). Asylums: Essays on the Social Situation of Mental Patients and Other Inmates. Harmondsworth. Penguin Books.

GRABURN, N. (2001). Secular Ritual: A General Theory of Tourism. In Smith, V. L. and Brent, M. (Eds) Hosts and Guests Revisited: Tourism Issues of the $21^{\text {st }}$ Century. New York. Cognizant: 4250.

GRÜNEWALD, R. (2002). Tourism and Cultural Revival. Annals of Tourism Research 29 (4): 10041021.

HALL, S. and DU GAY, P. (Eds) (1996). Questions of Cultural Identity. London. Sage

HARRISON, D. (1997). Globalization and Tourism: Some Themes from Fiji. In Oppermann, M. (Ed) Pacific Rim Tourism. Wallingford. CAB International: 167-183. 
HARRISON, D. (2005a). Introduction: Contested Narratives in the Domain of World Heritage. In Harrison, D. and Hitchcock, M. (Eds) The Politics of World Heritage: Negotiating Tourism and Conservation. Clevedon. Channel View Publications: 1-10.

HARRISON, D. (2005b). Levuka, Fiji: Contested Heritage. In Harrison, D. and Hitchcock, M. (Eds) The Politics of World Heritage: Negotiating Tourism and Conservation. Clevedon. Channel View Publications: 66-89.

HARRISON, D. and HITCHCOCK, M. (Eds) (2005). The Politics of World Heritage: Negotiating Tourism and Conservation. Clevedon. Channel View Publications.

HETHERINGTON, K. (1998). Expressions of Identity: Space, Performance, Politics. London. Sage.

HOFSTEDE, G., HOFSTEDE, G. and MINKOV, M. (2010). Cultures and Organizations $3^{\text {rd }}$ ed. New York. McGraw Hill.

HOLDEN, A. and WICKENS, E. (2007). Citizen of the World or Management Puppet? The Place of Tourism Studies in Higher Education. Tourism Recreation Research 32 (2): 41-47.

HOLLINSHEAD, K. (1998). Tourism, Hybridity and Ambiguity: The Relevance of Bhabha's 'Third Space' Cultures. Journal of Leisure Research 30 (1): 121-156.

HOPE, C.A. (2004). The Impact of National Culture on the Transfer of 'Best Practice Operations Management' in Hotels in St. Lucia. Tourism Management 25 (1): 45-59.

HOTTOLA, P. (2004). Culture Confusion: Intercultural Adaptation in Tourism. Annals of Tourism Research 31 (2): 447-466.

JACK, G. and PHIPPS, A. (2005). Tourism and Intercultural Exchange: Why Tourism Matters. Clevedon. Channel View Publications.

KARATEPE, O. (2010). The Effect of Positive and Negative Work-family Interaction on Exhaustion: Does Work Social Support Make a Difference? International Journal of Contemporary Hospitality Management 22 (6): 836-856.

KNUTSON, B. J., BECK, J. A., KIM, S. H. and CHA, J. (2006). Identifying the Dimensions of the Experience Construct. Journal of Hospitality and Leisure Marketing 15 (3): 31-47.

KNUTSON, B. J., BECK, J. A., KIM, S. and CHA, J. (2009). Identifying the Dimensions of the Guest's Hotel Experience. Cornell Hospitality Quarterly 50 (1): 44-55.

LUGOSI, P. (2009). The Production of Hospitable Space: Commercial Propositions and Consumer Co-Creation in a Bar Operation. Space and Culture 12 (4): 396-411. 
LUGOSI, P. (2014). Mobilising Identity and Culture in Experience Co-creation and Venue Operation. Tourism Management 40: 165-179.

LYNCH, P., GERMANN MOLZ, J., MCINTOSH, A., LUGOSI, P. and LASHLEY, C. (2011). Theorising Hospitality. Hospitality and Society 1 (1): 3-24.

MAOZ, D. (2005). The Mutual Gaze. Annals of Tourism Research 33 (1): 221-239.

MARS, G. and NICOD, M. (1984). The World of Waiters. London. George Allen and Unwin.

METUSELA, C. and Waitt, G. (2012). Tourism and Australian Beach Cultures: Revealing Bodies. Bristol. Channel View Publications.

MWAURA, G., SUTTON, J. and ROBERTS, D. (1998). Corporate and National Culture - An Irreconcilable Dilemma for the Hospitality Manager? International Journal of Contemporary Hospitality Management 10 (6): 212-220.

NICHOLLS, R. (2011). Customer-to-Customer Interaction (CCI): A Cross-cultural Perspective. International Journal of Contemporary Hospitality Management 23 (2): 209-223.

O'NEILL, J.W. (2012). The Determinants of a Culture of Partying Among Managers in the Hotel Industry. International Journal of Contemporary Hospitality Management 24 (1): 81-96.

PARSONS, T. and SHILS, E. (1951). Values, Motives and Systems of Action. In Parsons, T. and Shils, E. (Eds) Toward a General Theory of Action: Theoretical Foundations for the Social Sciences. New York. Harper and Row: 47-278.

PASMORE, W., FRANCIS, C., HALDEMAN, J. and SHANI, A. (1982). Sociotechnical Systems: A North American Reflection on Empirical Studies of the Seventies. Human Relations 35 (12): 1179 -

1204.

PEACOCK, M. and KÜBLER, M. (2001). The Failure of 'Control' in the Hospitality Industry. International Journal of Hospitality Management 20 (4): 353-365.

PEARCE, P. (1995). From Culture Shock and Culture Arrogance to Culture Exchange: Ideas Towards Sustainable Socio-Cultural Tourism. Journal of Sustainable Tourism 3 (3): 143-154.

PEARCE, P. (2005). Tourist Behaviour. Clevedon. Channel View Publications.

PI-SUNYER, O. (1989). Changing Perceptions of Tourism and Tourists in a Catalan Resort Town. In Smith, V. (Ed) Hosts and Guests: The Anthropology of Tourism. Philadelphia. University of Pennsylvania Press: 187-199. 
PRATT, S. (2013). Minimising Food Miles: Issues and Outcomes in an Ecotourism Venture in Fiji. Journal of Sustainable Tourism DOI: 10.1080/09669582.2013.776060 (In-press).

PRITCHARD, A. and MORGAN, N.J. (2006). Hotel Babylon? Exploring Hotels as Liminal Sites of Transition and Transgression. Tourism Management 27 (5): 762-772.

READ, S. (1986). Hello Campers. London. Transworld Publishers.

REISINGER, Y. (2009). International Tourism - Cultures and Behaviour. Oxford. ButterworthHeinemann.

RITZER, G. and LISKA, A. (1997). McDisneyization and 'Post-tourism': Contemporary Perspectives on Contemporary Tourism. In Rojek, C. and Urry, J. (Eds) Touring Cultures: Transformations of Travel and Theory. London. Routledge: 96-109.

ROGERSON, C. M. (2012). Strengthening Agriculture-tourism Linkages in the Developing World: Opportunities, Barriers and Current Initiatives. African Journal of Agricultural Research 7 (4): 616-623.

ROJEK, C. and URRY, J. (1997). Transformations of Travel and Theory. In Rojek, C. and Urry, J. (Eds) Touring Cultures: Transformations of Travel and Theory. London. Routledge: 1-19.

ROYLE, T. (1995). Corporate Versus Societal Culture: A Comparative Study of McDonald's in Europe. International Journal of Contemporary Hospitality Management 7 (2): 52-56.

RYAN, C. (2003). Recreational Tourism: Demand and Impacts. Bristol. Channel View.

SCHROEDER, K. and SPROULE-JONES, M. (2012). Culture and Policies for Sustainable Tourism: A South Asian Comparison. Journal of Comparative Policy Analysis 14 (4): 330-351.

SHERMAN, R. (2007). Class Acts: Service and Inequality in Luxury Hotels. Berkley. University of California Press.

SHIRLEY VALENTINE (1989) Dir. Lewis Gilbert, with Screenplay by Willy Russell. Paramount Pictures.

SOPER, A.K. (2008). Mauritian Landscapes of Culture, Identity, and Tourism. In Knudsen, D.C., Metro-Roland, M.M., Soper A.K. and Greer, C.E. (Eds) Landscape, Tourism and Meaning. Aldershot. Ashgate: 51-64.

TRAUER, B. and RYAN, C. (2005). Destination Image, Romance and Place Experience - An Application of Intimacy Theory in Tourism. Tourism Management 26 (4): 481-491. 
TRIBE, J. (2000). Balancing the Vocational: The Theory and Practice of Liberal Education in Tourism. Tourism and Hospitality Research 2 (1): 9-25.

TRIST, E. (1981). The Evolution of Socio-technical Systems. Occasional Paper No.2. Toronto. Ontario Quality of Working Life Centre.

TURNER, V. and TURNER, E. (1978). Image and Pilgrimage in Christian Culture. New York. Columbia University Press.

URBAIN, J-D (2003). (Translated by C. Porter) At the Beach. Minneapolis. University of Minnesota Press.

WALLS, A., OKUMUS, F., WANG, Y. and KWUN, D. (2011). Understanding the Consumer Experience: An Exploratory Study of Luxury Hotels. Journal of Hospitality Marketing and Management 20 (2): 166-197

WEAVER, A. (2005). Spaces of Containment and Revenue Capture: 'Super-Sized' Cruise Ships as Mobile Tourism Enclaves. Tourism Geographies 7 (2): 165-184.

WEBER, M. (1949). The Methodology of the Social Sciences. New York. Free Press.

WILLIAMS, A. (2006). Lost in Translation? International Migration, Learning and Knowledge. Progress in Human Geography 30 (5): 588-607.

WOOD, R. C. (1994). Hotel Culture and Social Control. Annals of Tourism Research 21 (1): 6580.

ZAITOUNI, M., BREAKEY, N. and ROBINSON, R. (2012). Do We Know What the Hotel Industry Expects From Graduates? Paper presented to the panel 'Changing Times in Tourism and Hospitality Education.' THE-ICE $6^{\text {th }}$ International Panel of Experts Forum, The Emirates Academy of Hospitality Management, Dubai, UAE. $18^{\text {th }}-20^{\text {th }}$ November. 